\title{
Integrated Clinical Pathways: Communication and Participation in a Multidisciplinary Team
}

\author{
Mateja Šimec*, Sabina Krsnik (D), Karmen Erjavec(D) \\ Faculty of Health Sciences, University of Novo Mesto, Novo Mesto, Slovenia
}

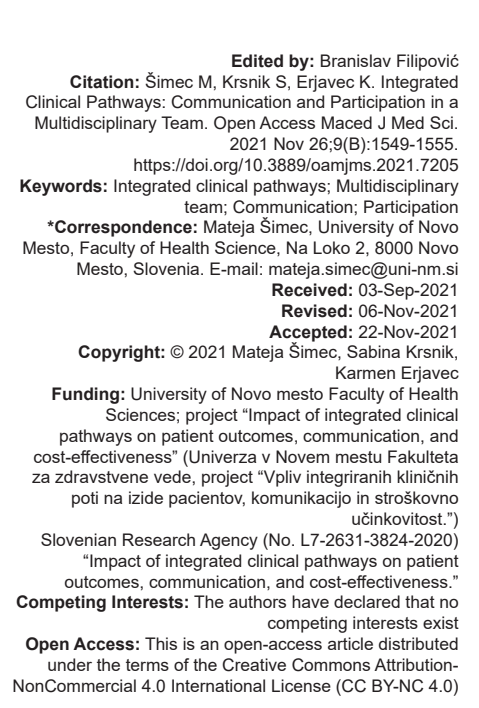

Abstract

BACKGROUND: An integrated clinical pathway (ICP) is a key method for structuring or planning processes of care enabling the modernization of health-care delivery and coordination of multiple roles, forming a complete, patientcentered multidisciplinary health-care team and establishing the sequence of activities, promoting individual and team communication, collaboration, networking, and transparency, and reducing the cost of care.

AIM: As there is a research gap in the area of communication among members of a multidisciplinary team for the treatment of patients through an ICP, the aim of this study was to determine the impact of communication of a member of a multidisciplinary team on the active participation of an individual in this multidisciplinary team.

METHODS: A cross-sectional study of three ICPs, forchronic kidney disease, stroke, and total hip arthroplasty was conducted in a typical Slovenian general hospital.

RESULTS: The results show that in the analyzed hospital, two of the three clinical pathways are not yet fully integrated.

CONCLUSION: There is a weak influence of staff communication within a multidisciplinary team on an individual's participation in this multidisciplinary team, indicating the need for various activities to actually implement clinical pathway "integration," and promote better communication within teams to strengthen participation in multidisciplinary patient care pathways.

\section{Introduction}

The health-care system seeks to improve comprehensive patient care, health outcomes, and cost-effectiveness in a variety of ways. The main method of structuring or planning care processes, which has been widely used in Slovenia, South-Eastern Europe, and the developed world in recent years, is the integrated care pathway, also known as integrated clinical pathway (ICP) [1]. It is still being monitored for many misunderstandings related to the unanimously accepted definition of an ICP and, in particular, the unclear inclusion of "integration" in the clinical pathway [2]; therefore, in this article, we use the word "integration" in brackets whenever it is unclear. The European Pathway Association defines a clinical pathway as "a methodology for shared decision-making and organization of medical care for a specific group of patients over a predetermined period of time" [3].

ICPs, which can be used in the implementation of health-care activities at all levels [4], enable the modernization of healthcare and the coordination of different roles, form a complete, patient-centered, multidisciplinary health-care team and define the sequence of activities, promote individual and team communication, cooperation, integration, and transparency of the work done [5], [6]. They also enable transparent the documentation, monitoring and evaluation of different deviations or outcomes, the involvement of patients and their relatives, and greater satisfaction among employed health-care professionals, their colleagues and patients [7]. The design of CPs is based on multidisciplinary teamwork and the incorporation of evidence-based interventions [8] and in the "integrated" form CPs extends beyond the boundaries of individual health facilities and involves all key healthcare and other care professionals [7]. The previous studies have shown that general practitioners (GPs) work well with specialists and poorly with other professional groups [9]. Due to the ageing of the population and the associated increased incidence of commonly treated diseases in elderly patients, such as chronic kidney disease, stroke, and total hip arthrosis [10], [11], [12], the research question is how ICPs improve the medical treatment of patient with 
chronic kidney disease, stroke and total hip arthroplasty and how ICPs actually realize "integration" in practice by involve all key players who are absolutely necessary for the comprehensive treatment of the patient in a multidisciplinary team.

The basis of successful ICP implementation is group collaboration and good communication within the team, with the management and patients/ relatives [13]. Interprofessional teamwork involving different service providers is an essential component of integrated care [14]. A specialized multidisciplinary team of health professionals specifically trained to work with stroke patients includes a doctor, a nurse, a physiotherapist, an occupational therapist, a speech therapist, a clinical psychologist, and a social worker [15], with communication and understanding of roles statistically contributing to multidisciplinary working stroke team [16]. A multidisciplinary team for total hip arthroplasty includes a surgeon (ideally with an anaesthesiologist), an orthopedic team leader and/or a joint program coordinator, a nurse in the surgical unit, an outpatient nurse in the surgical care unit, a nurse in the post-operative care unit, a member of the quality department, a physiatrist, a primary care provider, the patient, and family members [17]. Clinical pathways for patients with chronic kidney disease optimize their care while enabling better collaboration and communication between GPs and nephrologists, pharmacists, and nurses in the clinical setting [18]. Studies show that relevant health information shared effectively by members of a multidisciplinary team is still not sufficient for successful collaboration in care, as good teamwork requires effective communication and good joint treatment decision-making [19], [20], [21].

Effective communication, which conditions the establishment and maintenance of good relationships within the team [22], is critical to successful participation in a multidisciplinary team, with clear and concise verbal communication being crucial [23]. Poor communication among the members of a multidisciplinary team can lead to poor patient outcomes [24], [25], a threat to patient safety due to missing key information and its misinterpretation, and unclear instructions [26]. Good communication among health-care professionals and patients/relatives is considered an important moderating variable for achieving better health outcomes [27], [28]. Studies in the field of ICPs [13], [22], [29] have shown that for the successful implementation of a ICP the key lies in the active and competent participation of the individual health professional in interprofessional teams, where he or she contributes specialized knowledge and skills to solve complex health challenges, develops team communication strategies in terms of fostering collaboration among team members, sharing relevant information, and coordinating appropriate health decisions. The forms of communication for successful collaboration include addressing, listening, receiving, and sharing information with team members [30]. Since each member of a multidisciplinary team has specialized knowledge and experience that is essential to making informed decisions about patient care, it is critical that team members share relevant information with all team members and find the best ways to share knowledge and information [26]. As no study has yet been conducted on the impact of the way of communication in ICP on participation, the question arises what impact the way of communication of an individual in a multidisciplinary team ICP has on his/her participation in the team.

Studies show that health-care professionals involved in different ICPS are mostly quite satisfied with team communication [13], but physicians are often unaware of the responsibility for participation and communication in a multidisciplinary team when treating patients through an ICP [31]. Clinical communication, defined as a two-way, coordinated and continuous exchange of information between individuals, represents the timely, accurate and appropriate transmission of information about a patient's medical treatment through multiple channels [32], with direct communication being the key to establishing effective communication among health-care professionals [33]. It has been shown that strategic communication within the team is required [34], team leaders leading group discussions, coordinating information exchange, managing conflict, and making group decisions [22]. Although most existing studies [5], [13], [35] generally find a positive impact of ICPs on team communication, no research has been conducted to determine the impact of an individual's communication on his/her participation in a multidisciplinary team following a certain ICP.

Due to presented research gaps, the aim of the study was to determine the influence of communication of an individual in a multidisciplinary team on his or her participation in a multidisciplinary team following a certain ICP.

\section{Methods}

A cross-sectional study was conducted using a descriptive quantitative method with a survey. Data collection was part of the project "Impact of ICPs on patient outcomes, communication, and cost-effectiveness" funded by the Slovenian Research Agency (No. L7-2631-3824-2020). The research was approved by the National Medical Ethics Committee of the Republic of Slovenia (No. 0120-189/2021/3). At the request of respondents, the questionnaire was distributed in printed form. The completed questionnaires were collected from June 7 to July 15, 2021, in the Nephrology, Neurology and Orthopaedics Departments of the Novo mesto General Hospital. This hospital was selected because it represents a typical general hospital in Slovenia, one of the ten. 


\section{Research population}

The research population consisted of hospital employees, according to their roles: Doctor, nurse, physiotherapist, clinical pharmacist, social worker, clinical dietician, radiologist, health administrator, and hygienist. The inclusion criterion was participation in a multidisciplinary team involved in patient treatment. Data were collected through a survey; of the 163 included respondents, 144 completed the questionnaire. All respondents were informed of the purpose of the survey.

The sample was dominated by women ( $n=124,86.1 \%)$. Most $(28.5 \%)$ and also the same number $(n=41)$ of respondents were in the age groups from 21 to 30 years and from 31 to 40 years, and the fewest were $<20$-years-old (2.1\%). About $38.2 \%$ of the respondents had tertiary education, $34 \%$ had secondary education, $10.4 \%$ had a university degree, $11.8 \%$ had a specialization/master's degree, and 3.5\% had a PhD. The majority of respondents were members of a multidisciplinary team following the clinical pathway for the treatment of chronic kidney disease ( $n=57,39.6 \%$ ), and the fewest in a multidisciplinary team following the clinical pathway for the treatment of stroke $(n=35,24.3 \%)$.

\section{Description of the instrument}

To collect the data, we used a structured questionnaire with three sets, based on the questionnaire of Cramm and Nieboer study [16], adapted and supplemented for the needs of our research. The first set, "Participation in a multidisciplinary team," which determined the individual's collaboration with specific members of the multidisciplinary team, included six statements and a list of 35 roles of multidisciplinary team members in treating the patient following an ICP (from 1, "Never," to 5, "Very often"). The second set of questions measured the type of communication and individual communication, and the third captured socio-demographic data. The first question on the type of communication consisted of four statements, and the second question on individual communication included three statements, which participants rated on a five-point scale from 1 ("I don't agree at all") to 5 ("I totally agree"). The reliability of the instrument was acceptable $(\alpha=0.779)$. The third set, which included socio-demographic variables, contained five questions on gender, age, education level, occupation, and clinical pathway.

The questionnaire was translated from the original English version into Slovenian and then back into English in accordance with international scientific guidelines [36]. We compared the translation with the original, harmonized the discrepancies in content, and adapted it to the Slovenian context. The questionnaire was reviewed and commented on by seven healthcare professionals from the clinical setting, after which a pilot study was conducted $(n=50)$.

\section{Data analysis}

We used descriptive statistics and multiple linear regression analysis. A value of $p<0.05$ determined the limit of the statistical significance. Statistical analysis was performed using SPSS, version 23.0 (SPSS Inc., Chicago, IL, USA).

\section{Results}

\section{Participation in a multidisciplinary team}

The results showed that in the treatment of patients after a stroke, the members of the multidisciplinary team using the ICP participated most frequently with a registered nurse where the average value $(\mathrm{M})$ is $4.31(\mathrm{SD}=0.58)$, a nurse $(\mathrm{M}=4.23$; $S D=0.87)$, and relatives $(M=3.91 ; S D=1.27)$, followed by collaboration with a neurologist $(M=3.62$; $S D=1.53)$, an internist $(\mathrm{M}=3.34 ; \mathrm{SD}=1.4)$ and an emergency department doctor $(\mathrm{M}=3.12 ; \mathrm{SD}=1.81)$, less often they cooperated with a radiologist $(M=2.83$; $S D=1.77)$ and an anesthesiologist ( $M=2.74 ; S D=1.95)$, even less often with a social worker $(M=2.6$; $S D=1.75)$, a physiotherapist $(\mathrm{M}=2.54 ; \mathrm{SD}=2.07)$ and a $\mathrm{GP}$ $(M=1.54 ; S D=1.87)$, and very little with a nutritionist $(M=1.31 ; S D=1.82)$ and a psychologist $(M=1.03$; $\mathrm{SD}=1.03)$. They cooperated least with a clinical pharmacist $(\mathrm{M}=0.97 ; \mathrm{SD}=1.16)$ and the community service $(M=0.77 ; S D=1.02)$. There was no cooperation

Table 1: Assessment of individual participation in a multidisciplinary team in patient care

\begin{tabular}{|c|c|c|c|c|c|c|c|}
\hline \multirow[t]{2}{*}{ Arguments } & \multicolumn{5}{|c|}{ Answers } & \multirow[t]{2}{*}{$M$} & \multirow[t]{2}{*}{ SD } \\
\hline & Never & Rarely & Uncommon & Often & Very often & & \\
\hline $\begin{array}{l}\text { As member of the clinical pathway team, I rely on documentation to } \\
\text { monitor the patient's medical condition. }\end{array}$ & $\begin{array}{l}3 \\
(2.3 \%)\end{array}$ & $\begin{array}{ll}0 \\
(0 \%)\end{array}$ & $\begin{array}{l}15 \\
(11.4 \%)\end{array}$ & $\begin{array}{l}35 \\
(26.5 \%)\end{array}$ & $\begin{array}{l}79 \\
(59.8 \%)\end{array}$ & 4.42 & 0.87 \\
\hline $\begin{array}{l}\text { When I make decisions, I ask another competent person on the team for } \\
\text { an opinion. }\end{array}$ & $\begin{array}{l}0 \\
(0 \%)\end{array}$ & 6 & $\begin{array}{l}15 \\
(11.4 \%)\end{array}$ & $\begin{array}{l}37 \\
(28.0 \%)\end{array}$ & $\begin{array}{l}74 \\
(56.1 \%)\end{array}$ & 4.36 & 0.86 \\
\hline Team members inform each other about changes in the patient's health. & $\begin{array}{l}0 \\
(0 \%)\end{array}$ & $\begin{array}{l}0 \\
(0 \%)\end{array}$ & $\begin{array}{l}8 \\
(6.1 \%)\end{array}$ & $\begin{array}{l}23 \\
(17.6 \%)\end{array}$ & $\begin{array}{l}100 \\
(76.3 \%)\end{array}$ & 4.70 & 0.58 \\
\hline $\begin{array}{l}\text { As part of the clinical pathway, team members exchange opinions on the } \\
\text { necessary activities for the patient. }\end{array}$ & $\begin{array}{l}1 \\
(0.8 \%)\end{array}$ & $\begin{array}{l}4 \\
(3.1 \%)\end{array}$ & $\begin{array}{l}12 \\
(9.2 \%)\end{array}$ & $\begin{array}{l}28 \\
(21.4 \%)\end{array}$ & $\begin{array}{l}86 \\
(65.6 \%)\end{array}$ & 4.48 & 0.84 \\
\hline Team members plan and coordinate work together. & $\begin{array}{l}0 \\
(0 \%)\end{array}$ & $\begin{array}{l}3 \\
(2.3 \%)\end{array}$ & 7 & $\begin{array}{l}28 \\
(21.2 \%)\end{array}$ & $\begin{array}{l}94 \\
(71.2 \%)\end{array}$ & 4.61 & 0.70 \\
\hline $\begin{array}{l}\text { Team members make important decisions together and solve problems } \\
\text { successfully. }\end{array}$ & $\begin{array}{l}0 \\
(0 \%)\end{array}$ & $\begin{array}{l}2 \\
(1.5 \%)\end{array}$ & $\begin{array}{l}8 \\
(6.1 \%)\end{array}$ & $\begin{array}{l}30 \\
(22.9 \%)\end{array}$ & $\begin{array}{l}91 \\
(69.5 \%)\end{array}$ & 4.60 & 0.68 \\
\hline Together & & & & & & 4.54 & 0.52 \\
\hline
\end{tabular}


Table 2: Assessment of the type of communication

\begin{tabular}{|c|c|c|c|c|c|c|c|}
\hline \multirow[t]{2}{*}{ Arguments } & \multicolumn{5}{|l|}{ Answers } & \multirow[t]{2}{*}{$\mathrm{M}$} & \multirow[t]{2}{*}{ SD } \\
\hline & Idon't agree at all & I don't agree & I can't decide & I agree & I completely agree & & \\
\hline Communication within the team is limited to formal communication. & $\begin{array}{l}13 \\
(9.7 \%)\end{array}$ & $\begin{array}{l}75 \\
(56.0 \%)\end{array}$ & $\begin{array}{l}17 \\
(12.7 \%)\end{array}$ & $\begin{array}{l}22 \\
(16.4 \%)\end{array}$ & $\begin{array}{l}7 \\
(5.2 \%)\end{array}$ & 2.51 & 1.05 \\
\hline Conflicting communication prevails among team members. & $\begin{array}{l}26 \\
(19.1 \%)\end{array}$ & $\begin{array}{l}84 \\
(61.8 \%)\end{array}$ & $\begin{array}{l}14 \\
(10.3 \%)\end{array}$ & $\begin{array}{l}6 \\
(4.4 \%)\end{array}$ & $\begin{array}{l}6 \\
(4.4 \%)\end{array}$ & 2.13 & 0.93 \\
\hline Team members mostly communicate passively (respond poorly). & $\begin{array}{l}28 \\
(20.7 \%)\end{array}$ & $\begin{array}{l}82 \\
(60.7 \%)\end{array}$ & $\begin{array}{l}11 \\
(8.1 \%)\end{array}$ & $\begin{array}{l}12 \\
(8.9 \%)\end{array}$ & $\begin{array}{l}2 \\
(1.5 \%)\end{array}$ & 2.10 & 0.88 \\
\hline All team members are equally involved in team communication. & $\begin{array}{l}3 \\
(2.2 \%)\end{array}$ & $\begin{array}{l}21 \\
(15.7 \%)\end{array}$ & $\begin{array}{l}18 \\
(13.4 \%)\end{array}$ & $\begin{array}{l}61 \\
(45.5 \%)\end{array}$ & $\begin{array}{l}31 \\
(23.1 \%)\end{array}$ & 3.72 & 1.06 \\
\hline
\end{tabular}

with a speech therapist, occupational therapist and physiatrist in this multidisciplinary team.

Members of the multidisciplinary team using the ICP for total hip arthroplasty worked on average most frequently with a registered nurse $(\mathrm{M}=4.63 ; \mathrm{SD}=1.07)$, a nurse $(\mathrm{M}=4.51 ; \mathrm{SD}=1.22)$ and an orthopedist $(M=4.18 ; S D=1.27)$, followed by cooperation with an anesthetists $(M=3.90 ; S D=1.72)$, physiotherapist $(\mathrm{M}=3.87 ; \mathrm{SD}=1.86)$, relatives $(\mathrm{M}=3.49 ; \mathrm{SD}=1.81)$, and a radiologist $(\mathrm{M}=3.33$; $S D=1.71)$, somewhat less frequently with a social worker $(M=2.40 ; S D=1.67)$, an internist $(M=2.28$; $S D=1.34)$, infectiologist $(M=2.26 ; S D=1.34)$ and an emergency doctor $(M=1.96 ; S D=1.5)$, even less frequently with a dietician $(M=1.70 ; S D=1.69)$, a community service worker $(M=1.54 ; S D=1.45)$ and a $\mathrm{GP}(\mathrm{M}=1,48 ; \mathrm{SD}=1.77)$, and the least often with a psychiatrist $(M=1.28 ; S D=1.06)$, a psychologist $(M=1.17 ; S D=1.23)$, a clinical pharmacist $(M=1.07$; $S D=1.17$ ), and a coordinator in a rehabilitation facility $(\mathrm{M}=0.83 ; \mathrm{SD}=1.19)$. There was no collaboration with a physiatrist in this multidisciplinary team.

The analysis of the involvement of the multidisciplinary team using the ICP for the treatment of chronic kidney disease showed that its members collaborated most frequently with a registered nurse $(\mathrm{M}=4.7 ; \mathrm{SD}=0.87)$, a nurse $(\mathrm{M}=4.68 ; \mathrm{SD}=0.96)$, relatives $(M=4,18 ; S D=1.25)$, a nephrologist $(\mathrm{M}=4.09 ; \mathrm{SD}=1.23)$, and an internist $(\mathrm{M}=4.08$; $S D=1.31)$, followed by collaboration with a radiologist $(\mathrm{M}=3.43$; $\mathrm{SD}=1.52)$, a social worker $(\mathrm{M}=3.28$; $S D=1.36)$, an infectiologist $(M=3.23$; $S D=1.35)$, physiotherapist $(\mathrm{M}=3.2 ; \mathrm{SD}=1.77)$ and an emergency doctor $(M=3.13 ; S D=1.88)$, less frequently with a dietician $(\mathrm{M}=2.52 ; \mathrm{SD}=1.52)$ and an anesthesiologist $(\mathrm{M}=2.44 ; \mathrm{SD}=1.43)$, and even less with a clinical pharmacist $(\mathrm{M}=1.72 ; \mathrm{SD}=1.21)$, a psychiatrist $(\mathrm{M}=1.72 ; \mathrm{SD}=1.04)$ and $\mathrm{a} \mathrm{GP}(\mathrm{M}=1.6 ; \mathrm{SD}=1.71)$, and the least with the community service $(M=1.43$; $S D=1.32)$ and a psychologist $(M=1.21 ; S D=1.24)$.

\section{The influence of the type of}

\section{communication on participation in the team}

Table 1 shows that the assessment of average cooperation among the members of a multidisciplinary team following the patients using an ICP is relatively high $(\mathrm{M}=4.54)$. Team members are most likely to inform each other about changes in the patient's health status $(M=4.70)$, followed by joint planning and coordination of work among the team members $(M=4.61)$ and joint decision-making and successful problem solving ( $\mathrm{M}=4.60)$, and least often asking another competent person on the team for an opinion when making decisions $(M=4.36)$.

The largest proportion of respondents (65.7\%) estimated that communication within a multidisciplinary team using an ICP in the treatment of patients is not limited to formal communication (Table 2). Similarly, most believed that conflictual $(80.9 \%)$ or passive $(81.4 \%)$ communication is not prevalent among team members. The survey results showed that $68.6 \%$ of all team members were equally involved in team communication.

As showed in Table 3, an individual's participation in a multidisciplinary team was statistically significantly influenced by team communication or equal participation of all team members in communication ( $p<0.000$ ), while formal communication, conflict communication, and passive communication had no statistically significant influence. Overall, $15 \%$ of the variance of participation in a multidisciplinary team was explained by communication methods $(R=0.417$; $\mathrm{R}_{\text {pop }}^{2}=0.150 ; \mathrm{p}<0.000$ ).

Table 3: Influence of communication method on team participation - multiple regression model

\begin{tabular}{llllll}
\hline Statements & $\mathrm{B}$ & $\mathrm{SE}(\mathrm{B})$ & $\mathrm{B}$ & $\mathrm{t}$ & $\mathrm{p}$ \\
\hline $\begin{array}{l}\text { All team members are equally involved in } \\
\text { team communication. }\end{array}$ & 1.023 & 0.250 & 0.318 & 4.093 & 0.000 \\
$\begin{array}{l}\text { Communication within the team is limited } \\
\text { to formal communication. }\end{array}$ & 0.438 & 0.263 & 0.156 & 1.668 & 0.097 \\
$\begin{array}{l}\text { Conflict communication prevails among } \\
\text { team members. }\end{array}$ & 0.574 & 0.415 & 0.192 & 1.383 & 0.169 \\
$\begin{array}{l}\text { Team members mostly communicate } \\
\text { passively (react poorly). }\end{array}$ & -0.258 & 0.424 & -0.087 & -0.609 & 0.544 \\
\hline
\end{tabular}

\section{The influence of individual communication} on team participation

Table 4 shows that, on average, respondents agreed most with the statement that they could easily express their opinions among team members $(M=4.09)$ and least with the statement that team members listened to their opinions $(M=3.96)$.

Individual communication explained $22.9 \%$ of the variance in participation within a multidisciplinary team $\left(R=0.495 ; R_{\text {pop }}^{2}=0.229 ; p<0.000\right)$. Listening to opinions $(B=0.299 ; p<0.05)$ and solving communication problems ( $\beta=0.235$ ) had the greatest influence on team participation, among the independent variables 
Table 4: Assessment of individual communication within a team

\begin{tabular}{|c|c|c|c|c|c|c|c|}
\hline \multirow[t]{2}{*}{ Arguments } & \multicolumn{5}{|l|}{ Answers } & \multirow[t]{2}{*}{$\mathrm{M}$} & \multirow[t]{2}{*}{ SD } \\
\hline & I don't agree at all & I don't agree & I can't decide & I agree & I completely agree & & \\
\hline I can easily express my opinion among & $0(0 \%)$ & $7(5.1 \%)$ & $17(12.5 \%)$ & $69(50.7 \%)$ & $43(31.6 \%)$ & 4.09 & 0.80 \\
\hline By communicating in a team, I can easily solve a problem. & $1(0.7 \%)$ & $11(8.1 \%)$ & $15(11.0 \%)$ & $74(51.4 \%)$ & $35(25.7 \%)$ & 3.99 & 0.90 \\
\hline Team members listen to my opinion. & $3(2.2 \%)$ & $5(3.7 \%)$ & $22(16.2 \%)$ & $66(48.5 \%)$ & $40(29.4 \%)$ & 3.96 & 0.87 \\
\hline
\end{tabular}

Table 5: Influence of individual communication on team participation - multiple regression model

\begin{tabular}{llllll}
\hline Variables & $\mathrm{B}$ & $\mathrm{SE}(\mathrm{B})$ & $\mathrm{B}$ & $\mathrm{t}$ & $\mathrm{p}$ \\
\hline Expressing opinion & -0.044 & 0.531 & -0.010 & -0.082 & 0.934 \\
Listening to opinions & 1.168 & 0.518 & 0.299 & 2.257 & 0.026 \\
Resolving communication problems & 0.899 & 0.475 & 0.235 & 1.895 & 0.060 \\
\hline
\end{tabular}

included in the research/model, but the latter was not statistically significant (Table 5).

\section{Discussion}

The first study in the field of communication and cooperation of members of multidisciplinary teams using ICPs revealed a lack of involvement of the basic element of "integration." Although there are no studies that precisely define the involvement of individuals in different roles in a multidisciplinary team using ICPS for patient management, and as it depends on the context (organizational and social) [5], the existing studies [15], [18] indicate that in a multidisciplinary holistic patient care team all key players are involved, as according to Anderson and McDaniel [13], interprofessional teamwork involving different health-care providers is a key component of integrated care. Therefore, we may conclude/emphasize that the each of the multidisciplinary teams using ICPs included in our study lack some experts who are crucial for the holistic and integrated care of the patient. The hospital under study should urgently include a speech therapist, an occupational therapist and a physiatrist in the multidisciplinary team using an ICP for acute stroke, and a physiatrist in the multidisciplinary team using an ICP for total hip arthroplasty while treating patients in a multidisciplinary team. As for the multidisciplinary team using an ICP for chronic kidney disease, it already includes all key stakeholders, probably mainly at the expense of pre-treatment at the primary health-care level, and adequate staff representation of professionals, as staff shortages are a significant problem in other ICPs [18].

An individual's involvement in a multidisciplinary team to treat a patient using an ICP and their active participation are influenced by several factors. In our study, a statistically significant but weak association was found between how an individual communicates within the multidisciplinary team using an ICP and team participation, which is in line with the results of existing studies [33], [35]. This shows that although team member communication is important for participation, it is not crucial for team participation. We can conclude that the existing communication within the team is not such as to have a significant impact on team participation, which can be partly explained by the absence of important team members with whom team members could collaborate and partly by passive, distant, deep, and impersonal communication that makes employees indifferent about team participation [36]. Our research has shown that informing other team members of changes in the patient's health status and joint planning and coordination of work among team members is critical to the quality of members' participation in a multidisciplinary team, which has also been found in other studies [11], [13], [21]. The results also show that team members rarely ask for the opinion of another competent person in decision-making, which is an indicator of weak collaboration in general; this may be partly explained by the non-participation of individual key players in a multidisciplinary team.

The results also show that an individual's communication influences the individual's participation in a multidisciplinary team, and that it is particularly important to listen to the opinion of an individual team member. According to Dieleman et al. [29], team members listening to another team member's opinion is a key communication element of the individual's participation in a multidisciplinary team. In addition to listening, receiving and providing information to team members, it is critical for an individual's successful participation in a multidisciplinary team that each team member has specific knowledge and experience that is essential to making informed decisions about patient care [26]. It is critical that members of a multidisciplinary team using an ICP share relevant information with all team members and find the best ways to share knowledge and information.

The findings suggest that through various activities, such as quality analysis of the implementation of an ICP and additional training, the hospital should involve all key stakeholders for the actual "integration" of a CP and promote better communication and strengthen collaboration within multidisciplinary teams.

Despite the fact that this is the first study to determine the impact of staff communication in a multidisciplinary team on an individual's participation in a multidisciplinary team using an ICP, this study also has some limitations. The biggest one is that we conducted the research in one Slovenian hospital only. Although it is a typical Slovenian general hospital, we cannot generalize the results to all general hospitals in Slovenia and beyond. The results can only give us an insight into the challenges of implementing ICPs in Slovenia and in comparable countries. Another 
important limitation relates to the situation related to the COVID-19 epidemic, due to which work, communication and collaboration took place in a different way than before the epidemic.

\section{Conclusion}

A key element of an ICP is "integration" reflected in the inclusion of all key stakeholders in the multidisciplinary team using this approach. Two of the three ICPs - treatment of a patient with stroke and total hip arthroplasty - have not yet achieved full integration in the hospital analyzed.

There is a weak influence of staff communication within a multidisciplinary team on an individual's participation in a multidisciplinary team using an ICP, indicating the need for different activities to actually "integrate" ICPS, and to promote better communication within teams to strengthen participation in multidisciplinary teams.

\section{References}

1. Sleeman KE, Koffman J, Bristowe K, Rumble C, Burman R, Leonard $\mathrm{S}$, et al. It doesn't do the care for you: A qualitative study of health care professionals' perceptions of the benefits and harms of integrated care pathways for end of life care. BMJ Open. 2015;5(9):e008242. https://doi.org/10.1136/ bmjopen-2015-008242

\section{PMid:26369795}

2. Geršak K, Fras Z, Rems M. Do we know what good clinical guidelines should be? [Ali vemo, kakšne morajo biti dobre klinične smernice?]. Zdrav Vestn. 2016;85:6-14.

3. Dautremont JF, Rudmik LR, Yeung J, Asante T, Nakoneshny SC, Hoy $\mathrm{M}$, et al. Cost-effectiveness analysis of a postoperative clinical care pathway in head and neck surgery with microvascular reconstruction. J Otolaryngol Head Neck Surg. 2013;42:59. https://doi.org/10.1186/1916-0216-42-59

4. Deneckere S, Euwema M, Lodewijckx C, Panella M, Sermeus W, Vanhaecht $\mathrm{K}$. The European quality of care pathways (EQCP) study on the impact of care pathways on interprofessional teamwork in an acute hospital setting: Study protocol: For a cluster randomized controlled trial and evaluation of implementation processes. Implementa Sci. 2012;7:47. https:// doi.org/10.1186/1748-5908-7-47

PMid:22607698

5. Mater W, Ibrahim R. Situation analysis for clinical pathways and teamwork communication in healthcare. Indian J Sci Technol. 2016;9(28):1-4

6. Hajnrih B, Kadivec S, Kramar Z. In: Marusic D, Simcic B, editors. Clinical Pathways Design Guide [Priročnik za Oblikovanje Kliničnih Poti]. Ljubljana: Ministrstvo za Zdravje; 2009. p. 4-12.

7. Seys D, Panella M, VanZelm R, Sermeus W, Aeyels D, Bruyneel $\mathrm{L}$, et al. Care pathways are complex interventions in complex systems: New European pathway association framework. Int J Care Coord. 2019;22(1):5-9. https://doi. org/10.1177/2053434519839195

8. Aquino MR, Mullis R, Moore C, Kreit E, Lim L, McKevitt C, et al It's difficult, there's no formula: Qualitative study of stroke related communication between primary and secondary healthcare professionals. Int J Integr Care. 2020;20(4):11. https://doi. org/10.5334/ijic. 5465

PMid:33250676

9. Feigin VL, Norrving B, Mensah GA. Global burden of stroke. Circ Res. 2017;120(3):439-48. https://doi.org/10.1161/ CIRCRESAHA. 116.308413 PMid:28154096

10. Rubin S, Orieux A, Clouzeau B, Rigothier C, Combe C, Gruson $\mathrm{D}$, et al. The incidence of chronic kidney disease three years after non-severe acute kidney injury in critically ill patients: A single-center cohort study. J Clin Med. 2019;8(12):2215. https://doi.org/10.3390/jcm8122215

PMid:31847384

11. Lankhorst NE, Damen J, Oei EH, Verhaar JAN, Kloppenburg M, Bierma-Zeinstra SM, et al. Incidence, prevalence, natural course and prognosis of patellofemoral osteoarthritis: The cohort hip and cohort knee study. Osteoarthritis Cartilage. 2017;25(5):647-53. https://doi.org/10.1016/j.joca.2016.12.006 PMid:27940216

12. Everink IH, van Haastregt JC, Maessen JM, Schols JM, Kempen GI. Process evaluation of an integrated care pathway in geriatric rehabilitation for people with complex health problems. BMC Health Serv Res. 2017;17(1):34. https://doi.org/10.1186/ s12913-016-1974-5

PMid:28086867

13. Anderson RA, McDaniel RR Jr. Managing health care organizations: Where professionalism meets complexity science. Health Care Manage Rev. 2000;25(1):83-92. https:// doi.org/10.1097/00004010-200001000-00010

PMid:10710732

14. Dworzynski K, Ritchie G, Playford ED. Stroke rehabilitation: Long-term rehabilitation after stroke. Clin Med. 2015;15(5):461-4. https://doi.org/10.7861/clinmedicine.15-5-461

PMid:26430186

15. Cramm JM, Nieboer AP. Professionals' views on interprofessional stroke team functioning. Int J Integr Care. 2011;11:e081. https:// doi.org/10.5334/ijic.657

PMid:23390409

16. Integrated Care Pathway for Total Joint Arthroplasty Charlotte, NC: Premier, Inc., Institute for Healthcare Improvement; 2013. Available from: http://www.ihi.org/resources/pages/tools/ integratedcarepathwaytja.aspx [Last accessed on $2021 \mathrm{Apr}$ 20].

17. Elliott MJ, Gil S, Hemmelgarn BR, Manns BJ, Tonelli M, Jun $\mathrm{M}$, et al. A scoping review of adult chronic kidney disease clinical pathways for primary care. Nephrol Dial Transplant. 2017;32(5):838-46. https://doi.org/10.1093/ndt/gfw208 PMid:27257274

18. Van C, Mitchell B, Krass I. General practitioner-pharmacist interactions in professional pharmacy services. $J$ Interprof Care. 2011;25(5):366-72. https://doi.org/10.3109/13561820.2011.585 725

PMid:21657854

19. Grover A, Niecko-Najjum LM. Primary care teams: Are we there yet? Implications for workforce planning Acad Med. 2013;88(12):1827-9. https://doi.org/10.1097/ ACM. 0000000000000028

PMid:24128628

20. Chichirez CM, Purcărea VL. Interpersonal communication in healthcare. J Med Life. 2018;11(2):119-22.

PMid:30140317 
21. Kreps GL. Communication and effective interprofessional health care teams. Int Arch Nurs Health Care. 2016;2(3):51. Available from: https://www.clinmedjournals.org/articles/ianhc/ international-archives-of-nursing-and-health-care-ianhc-2-051. pdf [Last accessed on 2021 Apr 20].

22. Chen CS, Chan SW, Chan MF, Yap SF, Wang W, Kowitlawakul Y. Nurses' perceptions of psychosocial care and barriers to its provision: A qualitative study. J Nurs Res. 2017;25(6):411-8. https://doi.org/10.1097/JNR.0000000000000185 PMid:29099474

23. Robson W. Tools and techniques to improve teamwork and avoid patient harm. Nursing Times. 2016;113(1):24-7.

24. Gray $\mathrm{T}$. Safety huddle in a community nursing setting. $\mathrm{Br} J$ Community Nurs. 2020;25(9):446-50. https://doi.org/10.12968/ bjcn.2020.25.9.446 PMid:32881616

25. O'Daniel M, Rosenstein AH. Professional communication and team collaboration. In: Hughes RG, editor. Patient Safety and Quality: An Evidence-Based Handbook for Nurses. Rockville, MD: Agency for Healthcare Research and Quality; 2008. p. 33.

26. Evans-Lacko SE, Jarrett M, McCrone P, Thornicroft G. Clinical pathways in psychiatry. Br J Psychiatry. 2008;193(1):4-5. https:// doi.org/10.1192/bjp.bp.107.048926

PMid: 18700210

27. Vanhaecht K, De Witte K, Sermeus W. The care process organization triangle: A framework to better understand how clinical pathways work. J Integr Care Pathw. 2007;11:1-8.

28. Abdul Aziz AF, Mohd Nordin NA, Ali MF, Abd Aziz NA, Sulong S, Aljunid SM. The integrated care pathway for post stroke patients (iCaPPS): A shared care approach between stakeholders in areas with limited access to specialist stroke care services. BMC Health Serv Res. 2017;17(1):35. https://doi.org/10.1186/ s12913-016-1963-8

PMid:28086871
29. Dieleman SL, Farris KB, Feeny D, Johnson JA, Tsuyuki RT, Brilliant S. Primary health care teams: Team members' perceptions of the collaborative process. J Interprof Care. 2004;18(1):75-8. https://doi.org/10.1080/135618204100016393 70

\section{PMid:14668104}

30. Hogan C, Barry M, Burke M, Joyce P. Healthcare professionals experiences of the implementation of integrated care pathways. Int J Health Care Qual Assur. 2011:24:5:334-347. https://doi. org/10.1108/09526861111139179 PMid:21916088

31. Sibiya MN. Effective Communication in Nursing, Nursing, Nilgun Ulutasdemir, IntechOpen; 2018. p. 19. Available from: https:// www.intechopen.com/books/nursing/effective-communicationin-nursing. [Last accessed on $2021 \mathrm{Apr}$ 14].

32. Chan V, Patounas M, Dornbusch D, Tran H, Watson P. Is there a role for pharmacists in multidisciplinary health-care teams at community outreach events for the homeless? Aust J Prim Health. 2015;21(4):379-83. https://doi.org/10.1071/PY14158 PMid:25719905

33. Morgan S, Pullon S, McKinlay E. Observation of interprofessional collaborative practice in primary care teams: An integrative literature review. Int J Nurs Stud. 2015;52(7):1217-30. https:// doi.org/10.1016/j.jinurstu.2015.03.008 PMid:25862411

34. Helles $\varnothing$ R, Melby L, Brattheim B, Toussaint P. Integrating patient care across Norwegian healthcare settings-a ten-year perspective. Int J Integr Care. 2016;16(6):1-8.

35. Harkness JA. Questionnaire translation. In: Harkness JA van de Vijver F, Mohler P, editors. Cross-Cultural Survey Methods. Hoboken, NJ: John Wiley \& Sons; 2003. p. 35-56.

36. Buller MK, Buller DB. Physicians' communication style and patient satisfaction. J Health Soc Behav. 1987;28(4):375-88. PMid:3429807 